\title{
A Discussion on Risk Factors, Therapeutic Approach of Endometritis and Metritis in Cattle
}

\author{
Devender Kumar, Satish* and G.N. Purohit
}

Department of Veterinary Gynecology and Obstetrics, College of Veterinary and Animal
Sciences, Bikaner, RJUVAS Bikaner, Rajasthan 304001, India

*Corresponding author

\section{Keywords}

Endometritis, Metritis, Risk factors, Intrauterine therapy, Systemic therapy, Hormonal therapy

\section{Article Info}

Accepted:

04 April 2019

Available Online:

10 May 2019

\section{A B S T R A C T}

Metritis and endometritis are the very common postpartum uterine infections that results into infertility in dairy cattle, production loss and economical losses to the farmer. As postpartum uterus favors bacterial growth so it is frequently found in almost of unhygienic environment reared animals. Breaching of birth canal during dystocia, retention of placenta, wet environment during winter season and immunosuppression due to many reasons are the risk factors for the bacteria invasion to uterus. Although in normal condition these infections are eliminated in animals by uterine involution, passage of lochia, and through the mobilization of immune defense system within few weeks after parturition. Bacterial products causes inflammation, suppress pituitary LH secretion, and postpartum ovarian follicular growth and function, which disrupts ovulation, makes cattle infertile and can cause some severe systemic illness, even death of animal. Metritis and endometritis generally treated with the systemic antibiotics. As many study suggested that there is not so significant beneficial effect of intrauterine antibiotic infusions but not to be negated as some found positive effect. Neomycin is only labeled drug for intrauterine preparations. Ceftiofur and oxytetracycline parentally are good choice for the treatment of metritis and endometritis. Thus, metritis and endometritis affected animal having lower conception rates, increased intervals from calving to first service or conception.

\section{Introduction}

After parturition, uterine involution, regeneration of the endometrium, return of ovarian cyclic activity and the control of pathogenic bacteria in the uterus is required before cows are likely to conceive again (Gautam et al., 2009). Uterine infections during the postpartum period such as metritis and endometritis affect a large population of cattle and are associated with economical as well as production losses in dairy animals (Fourichon et al., 1999, 2000).

Calving associated problems such as dystocia, twins, retained placenta, and stillbirth are the common risk factors for development of metritis and endometritis (Grohn et al., 1990; Correa et al., 1993). Metritis is characterized as more severe inflammatory response to 
bacterial infection that occurs within all the layers of the uterus as endometrium, submucosa, myometrium and perimetrium are involved (Sheldon et al., 2006).

Up to $40 \%$ animals develop metritis within the first 14 days of calving and 10 to $15 \%$ of these animals have persistent infection for another three weeks leading to a chronic uterine disease that involving only the endometrium affects (Sheldon and Dobson, 2004).

Normal Uterine function are affected by pathogenic bacterial contamination after calving, causing uterine disease that are causes of infertility. The postpartum uterine lumen environment supports the growth of various types of bacteria (Ruder et al., 1981). Generally bacteria that contaminate the uterine lumen are removed by different types of uterine defense mechanisms. Under following normal condition cows eliminate these bacteria during the first 5 weeks after parturition, but in 10-17\% of animal infection occurs which causes uterine disease (Olson et al., 1984). It has been mentioned that bacterial load in uterus, bacterial metabolic products and the associated inflammation of uterine layers causes to suppress pituitary LH secretion that leads to disturbance postpartum ovarian follicular growth and function (Herath et al., 2009).

Cows affected by metritis and endometritis with systemic symptoms require systemic antibiotic with sportive treatment because of severe illness and risk for death but criteria for assessing treatment success are inconsistent (LeBlanc, 2008). Thus, uterine infection ultimately leads to lower conception rates, increased intervals from calving to first service or conception and had to more cattle culled for failure to conceive (Kossaibati and Esslemont, 1997; Esslemont and Kossaibati, 2002).

\section{Risk factors affecting postpartum reproductive function}

\section{Body condition score}

There are practically very few reports on the direct relationship between body condition score at the time of calving and incidence of postpartum infection in dairy cows. Reports stats that the body condition of beef cows is related to many critical aspects of production such as conception rate, calving interval, days to estrus, and milk production. When cows are extremely thin $(\mathrm{BCS}<4)$, they are not only reproductively inefficient, but they are most susceptible to health problems (Beverly 1985; Selk et al., 1986). On the other hand (Gautam et al 2010) found no significant effect of body condition score on the incidence of postpartum endometritis.

\section{Parity}

Postpartum ovarian activity, days from calving to ovulation and the number of follicular waves to first ovulation may require longer interval in primiparous cows compared to in multiparous cows, somaybe it is a predisposing factor of post partum infection (Lucy et al., 1992).

Cows in advance parity having more chances to develop uterine infections probably because of more relaxed birth canal and, delayed involution of uterus (Zezula et al., 1990). Puerperal metritis tends to develop in cows having parity less than 3 because of uterine tissue damage during dystocia (Bruun et al., 2002). Primiparous cows having higher risk of clinical endometritis compared to toward second-parity cows (Aghamiri et al., 2014). Reports also support the risk of puerperal metritis was highest following first calving and lowest in second parity cows (Markusfeld, 1987). Thus the effect of parity on incidence of uterine infections to be inconsistent. 


\section{Season}

Calving season is known to affects postpartum reproductive function. Early involution occurs in dry season rather than in rainy season, dry season also having reduced number of pathogen in environment (Rekwot et al., 2000). But some studies found no significant effect on uterine involution period due to calving season (Campo et al., 2002).

Reports of some studies revealed positive association between retention of fetal membranes with a seasonal pattern that contributes uterine infections. During winter season reduced feed intake results in negative energy balance that leads to metritis and retention of fetal membrane (Buckley et al., 2010). Immunosuppression and decreased leukocyte activity occurs in winter seasons increases the risk of uterine infection (Onyango, 2014). During winter months lack of grazing, thus increasing energy expenditure for maintenance, overcrowding, reduced exercise and less access to sunlight, stress increases the risk of postpartum uterine disease (Cady, 2010).

\section{Age}

It is difficult to state any comment for metritis in relation with the age of animal. Cattle have most susceptible to uterine infection at early age (Brunn et al., 2002). A study found lowest incidence of postpartum metritis in cows between 2 and 4 years of age and was highest in cows older than 7 years (Smith and Risco, 2002). Young cows have a small pelvis compared to older cows and thus are more prone to uterine injuries dystocia and thus predisposing them to uterine infections (Konyves et al., 2009; Tsousis et al., 2009; Potter et al., 2010). Tsousis et al.,(2009) found out that cows in their first parity had more purulent discharge compared to older cows which could be a result of calving assistance.
(LeBlanc et al., 2002) found that endometritis is more prevalent in mature cows in their third or higher parity had a prevalence of $21 \%$ compared to $13 \%$ for cows in first and second parity The frequency of postpartum metritis was significantly lower (21.42 per cent) in animals aged under 4 years as compared to 39.17 per cent in animals aged 4 to 8 years and 54.76 per cent in animals aged over 8years (Somasekara, 2003).

\section{Dystocia}

Assisted calving during parturation often results in postpartum uterine infections (Foldi et al., 2006; Tsousis et al., 2009) probably due to handling injuries or poor hygiene.

Dystocia also results in injury to uterine tissue due to oversized or malpresented calf can cause injuries to the genital tract during traction and retropulsion, which predispose it made it easy to invaded by pathogens and leads to uterine infection (Kim and Kang, 2003; Zaborski et al., 2009). Multiple births increased the chances of dystocia which also contribute post-parturient infections (HosseinZadeh, 2010). Dystocia results in delays the process of uterine involution by disturbing the hormonal events resulting in placental retention and predisposes cows for uterine infection (Smith and Risco, 2002). Injury during dystocia leads to release of heparin at the site of injury which inhibits collagenases and can also delay uterine involution and leads to retention of foetal membranes (Beagley et al., 2010).

\section{Retention of Foetal Membranes (RFM)}

According to many reports, there is a very close association between RFM and incidence of postpartum endometritis in dairy cattle. In cattle, failure to expel foetal membranes within 12 to 24 hours is considered as retention of foetal membranes (Drillich et al., 
2003). Contamination of this uterus by pathogens due to RFM affects animal fertility because it disrupts the normal endocrine control of ovarian activity, follicular development, and its lead to repeat breeding and makes it prone to higher risk of metritis and endometritis (Opsomer and Kruif, 2009). Retention of fetal membranes can also causes general health hazards that finally affect the reproductive performance of animal (Van Werven et al., 1992). Decrease of the antioxidant enzymes secreting capacity of the placenta during pregnancy can also lead to the retention of foetal membranes. Dystocia and uterine trauma also have been associated with uterine atony that inhibits expulsion of membranes and lead to uterine infections ( $\mathrm{Au}$ et al., 1992Eiler and Fecteau, 2007). Retention of foetal membranes causes delayed uterine involution, increased services per conception, longer time to 1 st service, decreased pregnancy rates and increased days open. Including metritis RFM also have been associated with increased risk for endometritis, ketosis, and mastitis (McDougall, 2001; Bruun et al., 2002). Animals with lower prepartum levels of placental superoxide dismutase and plasma estrogen level, subsequently developed retention of foetal membranes. (Gupta et al., 2005).

\section{Milk yield}

The milk yield for standard 305 days lactation was almost identical to healthy cows (Menadoric et al 1979; Markusfeld, 1984). In uterine infection affected cow some studies found that high producing cows had a higher incidence of postpartum reproductive disorders including metritis than low producing cows (Buttler and Smith, 1989). But in other study found significantly higher incidence of chronic postpartum endometritis in animals with low milk yield as compared to those with high milk yield (Somasekara,
2003). So it is not to conclude that high productive cows did not necessarily show always higher incidence of postpartum disorders (Nakova et al., 1992). In view of above and related other reports, it is difficult to assess whether the low milk yield is a risk factor for postpartum endometritis or the high milk yield itself.

\section{Miscellaneous factors}

Several miscellaneous factors have been reported to predispose the development of postpartum endometritis in dairy cows. Parturient abnormalities such as still birth) have been identified as significant factors for postpartum endometritis in dairy cows (Markusfeld 1984; Correa et al., 1993). The incidence of puerperal metritis was also reported to be higher in animals with short gestation length, following induction of parturition and multiple births (Muller and Owens 1974; Sandals et al., 1979; Juchle 1981; Markusfeld 1984 and Erb et al., 1985). Those animals suffering with post parturient metabolic diseases such as milk fever and ketosis are reportedly more prone for the development of puerperal metritis (Morrow 1969; Kendric 1980; Markusfeld 1984; Correa et al., 1993).

\section{Diagnostic methods-}

\section{History and physical examination}

The simplest approach for diagnosis of clinical endometritis is manual examination of vagina and expultion of the mucus from uterus for inspection. Such technique is considered inexpensive, quick and provides additional sensory information about such as detection of vaginal lacerations and detection of odor of mucus in vagina. (Sheldon et al.,2002). Post partum endometritis is diagnosed as persistent purulent or mucopurulent uterine discharge after 26 days 
in milking (LeBlanc, 2008). Hendricks et al (2006) found in there study clinical endometritis at days 50 of postpartum was suspected as $20 \%$ on the basis of purulent discharge detected by farmer by visual inspection of the prenium, vulva, tail, and further confirmed by clinician as trans-rectal palpation of uterus. Same as Somasekara (2003) states incidence of chronic postpartum metritis as $20.3 \%$ animals diagnosed on the basis of a history of mucopurulent discharge noticed by the animal attendant.

\section{Vaginoscopy}

Visual inspection of the canal vaginal using a sterile metal or transparent barrel vaginoscopy with a light source (Vaginoscopy) has been used to inspect the presence of pus or abnormal accumulates (Runciman et al.,2008a; Leutert et al., 2012). Vaginoscopy has been considered as more sensitive method than simple external inspection for detection of purulent discharge (Dohmen et al.,1995; Le Blanc et al., 2002a). Vaginoscopy provides proper image of the all female animal reproductive organ to identify endometritis and metritis (Miller et al.,1980; Dohmen et al., 1995; Williams et al.,2005; Leutert et al., 2012) but vaginitis, cervicitis and cystitis may give false results. Vaginoscopy is convenient to use yet there is risk of disease transmission if not used with proper hygiene (LeBlanc et al., 2002a).

\section{Transrectal palpation of the uterus}

For clinical endometritis transrectal palpation is most common means of diagnosis but palpation correctly identified only $22 \%$ of cows predicted to have uterine infection, compared to uterine culture (Miller et al., 1980). On perrectal palpation it is terribly subjective and it's going to be troublesome to differentiating the female internal reproductive organ undergoing involution from postpartum endometritis, particularly within the initial two weeks of parturation. (Youngquist and Shore, 1997; Smith and Risco, 2002).

\section{Transrectal ultrasonography}

Ultrasonography has become an important diagnostic tool for evaluating the female reproductive system. Its importance in diagnosis lies within the non-invasiveness of the instrument (Carriere et al., 2002). Anechoic fluid found in cases of endometritis along with snowy echogenic particles observed (Lenz et al., 2007; Barlunda et al., 2008). More recently transrectal ultrasonography has been used to detect intrauterine fluid accumulation associated with endometritis or metritis (Lenz et al., 2007; Oral et al., 2009; Melcher et al., 2014).

Ultrasonographic features also helpful in diagnosis of increased endometrial thickness (Lenz et al.,2007; Oral et al., 2009; Purohit et al., 2013). In an attempt to increase diagnostic ability combined the results of endometrial cytology and an ultrasonographic evaluation of fluid in the uterus and could improve both specificity and sensitivity considerably (Kasimanickam et al., 2004).

\section{Uterine cytology}

Subclinical endometritis is known to occur beyond 8 week postpartum and hamper fertility. During recent years uterine cytology has been used to diagnose subclical endometritis in dairy cows. For cytologycal study different approaches for collecting sample viz. using uterine biopsy, uterine lavage and cytobrush were adopted (Kasimanickam et al., 2005).

Endometrial cytobrush cytology was the most reliable method of diagnosing endometritis in cattle (Barlund et al., 2008). The collected 
swabs are rolled on glass microscopic slides and have been evaluated after staining with modified Wright or Giemsa staining. Prepared smear must contain epithelial cells (to confirm correct site of collection), if no epithelial cells are seen, there is no assurance that the sample was taken from the uterus (Azawi, 2008).

A positive endometrial cytology having $>18 \%$ nutrophils at 20-33 days postpartum or with $>10 \%$ nutrophils at 34-47 days postpartum are considered diagnostic indication (Kasaimanickam et al., 2004). Another technique is the low volume uterine flush to collect samples for endometrial cytology from cows between 40 and 60 days in milking (Gilbert et al.,2005). Samples in this approach was only 2-5 $\mathrm{ml}$ fluid yet before staining it was suggested to be re-suspended and centrifuged by cytospin centrifuge (Foldi et al., 2006).

\section{Microbial culture}

For definitive diagnosis of clinical endometritis microbiological examination of swabs collected from uterine lumen has been suggested, yet the difficulty in obtaining samples representative of the uterus limit the frequent use of such approach (Purohit, 2008). Swab is most accurate means of obtaining samples for identification of bacteria that cause infection (Olson et al., 1986; Noakes et al., 1991; Bonnett et al., 1993).

Bacterial culture determine the microbes (Studer and Morrow, 1978; Olson et al., 1986; Bretzlaff, 1987; Sheldon et al., 2004) in the uterus causing the pathology. By swabs collected from uterine lumen of dairy cows 21 and 28 days after calving, purulent vaginal mucus was associated with growth density of pathogenic bacteria but not opportunist contaminants (Dohmen et al., 1995; Williams et al., 2005; Westermann et al., 2010).

\section{White side test}

The coagulation of cervico-vaginal mucus on boiling with 5 percent $\mathrm{NaOH}$ with resultant appearance of yellow color was taken as positive indication of infection in uterus. On the basis of intensity of colour development, the degree of endometritis was classified as [1] No colour means absence of infection, [2] mild yellow colour change means mild infection), [3] intense yellow colour means severe infection (Anilkumar and Devanathan, 1996). However due to inconsistent results such test have not been validated (Purohit, 2008) and suggested (Raja et al.,2012).

\section{Endometrial biopsies}

Endometrial biopsy is highly diagnostic for pathology and has potential to generate extensive quantitative data on physiologic or immune mechanisms in cows.

The definitive diagnosis of clinical endometritis has been suggested based upon histological examination of endometrial biopsies (Bonnett et al., 1993; Meira Junior, 2010; Dolatkhah et al., 2013). Endometrial tissue is obtained with a biopsy punch by biopsy catheter, Ideal sample size of tissue is 10-20mm $\times 3 \mathrm{~mm}$ (De Bois and Manspeaker, 1986).

Histologically endometritis is characterized by disruption of endometrial epithelium, infiltration of inflammatory cells, accumulation of lymphocytes, vascular congestion and stromal edema (Bonnett et al., 1991; Bondurant, 1999; Meira Junior et al., 2012). However uterine biopsy followed by histologic examination is costly, time consuming, and not clinically accessible under most situations. Moreover uterine 
biopsy is an invasive technique and in cows has been associated with a detrimental effect on subsequent fertility (Miller et al.,1980; Bonnett et al.,1993).

\section{Hysteroscopy}

It is a non-invasive, non-delterious approach for the diagnosis of clinical endometritis in cows, (Madoz et al., 2010). It is a very useful tool to diagnose, or interpretate physiological and pathological changes during the postpartum period in cow (Devine and Lindsay 1984; Metzner et al., 1992).

However due to its high cost of the equipment and the problems encountered with passing the bovine cervix the prospects of such a technique are currently limited and suggested for specialized cases only (Milosh et al., 2013).

\section{Therapy}

Postpartum metritis is generally treated with antibiotics, hormones, alone or in combination. Antibiotics are used as systemically or locally into the uterine lumen. Animals with further health complications to suggested to be treated with antiinflammatory agents with fluid therapy and other supportive therapy as priority basis (Pugh, 1994).

It is still controversial whether cattle without any signs of systemic illness should be treated with systemic antibiotics.

Response to different therapies is variable because several factors like the differences in criteria used to diagnose metritis, the postpartum stage of the animals, the outcome variables that are being measured, and the route, frequency of administration of drug and different drugs used in each trial varies widely (Smith and Risco, 2002).
Uses of antibiotics in cases of retained placenta as prophylactic measure may be useful, but there are few studies evaluating their ability to prevent metritis, especially in relation to their cost and appropriate withdrawal times (Peters and Laven, 1996).

\section{Intrauterine infusions}

A variety of agents, antiseptic or antibiotics have been infused into the uterus in an attempt to destroy the infection, enhance uterine defense mechanisms, and increase uterine tone and also blood flow.

The ideal antibiotic should have ability to eliminate harmful bacteria from the uterus without damaging the uterus and impairing uterine defense mechanisms. As reports shown, intrauterine antibiotic infusion are not so effective treatments for postpartum metritis (Smith and Risco, 2002). When intrautrine antibiotics used, it is unclear whether the drug is distributed throughout all layers of the uterus (Bar and Ezra, 2005). Since in metritis, the infection is present into the deeper structures of the uterus and possibly to the serosal surface, intrauterine infusion achieves higher drug concentration in endometrium as compare to systemic antibiotics, but there is little penetration to deeper layers of uterus and genital tissues (Masera et al., 1980; Bretzlaff et al., 1983).

Although neomycin only is labeled for bovine intrauterine therapy (Veterinary Pharmaceuticals 1988) but rather than it these Intrauterine agents used are Lugol's iodine (Callahan and Horstman, 1987), gentamycin, spectinomycin, sulphonamides, nitrofirazone, iodine and chlorhexidine (Gustafsson, 1984; Gilbert and Schwark, 1992), florfenicol (Li Yan and Ji Lian, 2008), ceftriaxone (Mahto et al., 2012), Moxifloxacin (Purohit et al., 2013), cefquinome (Amiridis et al., 2003), cephapirin (McDoughall, 2001; Runciman et 
al., 2009; Kumar et al., 2013; Zobel, 2013) Ciprofloxacin (Purohit and Sharma, 2007; Sunilchandra and Hiremath, 2004). Intrauterine therapy as combination of 2 or 3 antibiotics Gentamycin, Chloramphenicol and Enrofloxacin has also been reported (Sood $e t$ al., 2002).

In cyclic cattle, use of irritable intrauterine drugs may induce prostaglandin release luteolysis and removal of the inhibitory effects of progesterone on the uterine defense mechanism (Paisley et al., 1986).This might be a cause for use of irritating intrauterine agents, but it should be discouraged (Bretzlaff, 1987). Nitrofurazone, commonly available, has reduced effectiveness in the presence of pus, blood and necrotic debris and is also quite irritating to the endometrium (Gustafsson, 1998; Olson, 1985). The iodine solutions infusion with saline is most popular but studies have also proven that potential harmful effects of iodine infusion on future reproductive performance of animal. It has been studied that a single infusion of 50-100 $\mathrm{ml}$ of $2 \%$ polyvinylpyrrolidoneiodine (povidone-iodine) solution, as a routine therapy for 30 days postpartum, shown adverse effect on fertility in cattle treated with endometritis compared to control group animals (Youngquist and Shore, 1997). Aminoglycosides are not effective as intrauterine infusion because it require aerobic environment to be effective (Olson et al., 1985). Lugol's iodine, streptomycin and oxytetracycline are irritating and are reported to cause coagulation necrosis of endometrium (Gilbert and Schwark, 1992). Strong iodine solutions will cause endometrial necrosis and return to estrus within 4-7 days. The irritation caused by the disinfectant has been demonstrated to invoke a prostaglandin release with subsequent luteolysis and return to estrus (Sequin et al., 1974). Oxytetracycline intrauterine therapy administration shown to very effective in treatment and prophylaxis of postpartum endometritis in cows (Singh et al.,2001; Malinowsk et al.,2004).Its antibacterial efficacy against almost infections caused by Gram-positive and Gram-negative bacteria are well-documented (Bretzlaff, 1986; Konigsson et al., 2001). All intrauterine antibacterial have been negative effects on normal leukocyte function and their placement risks iatrogenic contamination and further injury to the uterus (Paisley et al., 1986).

\section{Intrauterine antibiotic dosages}

\begin{tabular}{|c|c|c|}
\hline Antibiotic & Dosage & Comments \\
\hline Amikacin & 1 to 2 grams & Buffer with sodium bicarbonate \\
\hline Ampicillin & 1 to 3 grams & $\begin{array}{l}\text { Use soluble product, may be } \\
\text { irritating when concentrated }\end{array}$ \\
\hline $\begin{array}{l}\text { Ceftiofur sodium } \\
\text { negative }\end{array}$ & 1 gram & \\
\hline $\begin{array}{l}\text { Chloramphenicol } \\
\text { negative }\end{array}$ & 2 to 3 grams & Can be irritating \\
\hline Gentamicin & 1 to 3 grams & Acidic: Need to dilute and/or buffer \\
\hline Neomycin & 2 to 4 grams & \\
\hline Potassium penicillin & 5 million IU & \\
\hline Procaine penicillin & 4.5 to 6 million IU & Concern about residue left in uterus \\
\hline Ticarcillin & 3 to 6 grams & Infuse with 150 - to $200-\mathrm{mL}$ solution \\
\hline Pseudomonas & & \\
\hline $\begin{array}{l}\text { Ticarcillin with } \\
\text { clavulanic acid }\end{array}$ & 3 to 6 grams & Lactamase inhibitor \\
\hline
\end{tabular}

\footnotetext{
Major Bacterial Susceptibility

Gram negative

Gram positive and E. coli Gram positive and Gram

Gram positive and Gram

Gram negative

Gram negative

Gram positive

Gram positive

Gram positive,

Same as ticarcillin plus more Gram positive (Staph, .

Bacillus, Enterobacter)
} 
Sulfonamide is a useless drug for intrauterine therapy. Necrotic tissue and purulent debris reduce the efficacy of sulfonamides, Pus and necrotic debris present in the infected uterus provide the metabolites needed by the bacteria to produce folic acid (Olson et al., 1985). The penicillin family of drugs (Singh et al., 2001; Smith and Risco, 2002) and the cephalosporin tend to perform poorly when infused in the first 30-days postpartum because there are a number of organisms producing inactivating $\beta$-lactamase enzymes (Smith and Risco, 2002). Moreover, because many agents administered into the uterus may be systemically absorbed to some extent, there are concerns about appropriate meat and milk withdrawal periods (Gustafsson, 1984).

\section{Systemic antibiotics}

Systemic antibiotic therapy is having so many advantages. Withdrawal period of systemic antibiotic are well-known, distribution to all layers of the uterus is achieved, and systemic antibiotic appears to be less harmful to the uterine environment then intrauterine antibiotics (Smith and Risco, 2002).

Penicillin is most common antibiotic for postpartum metritis because it penetrates all layers of the uterus, is inexpensive, (Smith and Risco, 2002) and almost of the bacteria penetrate the endometrium those are sensitive to penicillin. Withdrawl period of penicillin in Milk 96 hours and for meat 10 days after the last treatment (Ott, 1996).

Ceftiofur sodium at $1 \mathrm{mg} / \mathrm{kg}$ IM or $\mathrm{SC}$ administered for 3 to 5 days with there no withdrawal period required. It was found that Ceftiofur concentrate in uterine tissues at levels exceeding then the mean inhibitory concentrations for Escherichia coli, Arcanobacter pyogenes, and Fusobacterium necrophorum (Smith and Risco, 2002). In another study administration of ceftiofur $(1 \mathrm{mg} / \mathrm{kg}$ IM) for 3 days to cows having clinical endometritis at 21-27 days after calving resulted in clear vaginal discharge at 41-42 days of calving.(Kaufmann et al.,2010; Bartolome et al.,2014).

\section{Systemic Antibiotic Dosages}

\begin{tabular}{ll} 
Antibacterial Antibiotics & \multicolumn{1}{c}{ Drug Dosage } \\
Amikacin & $10 \mathrm{mg} / \mathrm{kg} \mathrm{q} 24 \mathrm{~h}$ \\
Ampicillin & $29 \mathrm{mg} / \mathrm{kg} \mathrm{q} 12$ to $24 \mathrm{~h}$ \\
Ceftiofur & 2 to $4 \mathrm{mg} / \mathrm{kg} \mathrm{q} 12$ to $24 \mathrm{~h}$ \\
Doxycyline & $10 \mathrm{mg} / \mathrm{kg} \mathrm{q} 12 \mathrm{~h}$ \\
Enrofloxacin & $5.5 \mathrm{mg} / \mathrm{kg} \mathrm{q} 24 \mathrm{~h}$ \\
& $7.5 \mathrm{mg} / \mathrm{kg} \mathrm{q} 24 \mathrm{~h}$ \\
& $4.0 \mathrm{mg} / \mathrm{kg} \mathrm{q} 12 \mathrm{~h}$ \\
Gentamicin & $6.6 \mathrm{mg} / \mathrm{kg} \mathrm{q} 24 \mathrm{~h}$ \\
Metronidazole & $15 \mathrm{to} 25 \mathrm{mg} / \mathrm{kg}$ \\
Oxytetracycline & $6.6 \mathrm{mg} / \mathrm{kg} \mathrm{q} 12 \mathrm{~h}$ \\
Potassium penicillin & $22,000 \mathrm{IU} / \mathrm{kg} \mathrm{q} 6 \mathrm{~h}$ \\
Procaine penicillin & $22,000 \mathrm{IU} / \mathrm{kg} \mathrm{q} 12 \mathrm{~h}$ IM, only $10 \mathrm{~mL}$ \\
Trimethoprim sulfa & $30 \mathrm{mg} / \mathrm{kg} \mathrm{q} 12 \mathrm{~h}$ \\
IV, intravenous; IM, intramuscular; PO, per os; IU, international units
\end{tabular}

Route, Comment
IV or IM
IV or IM
IV or IM
PO
IV
Per os
Per os
IV or IM
PO
IV, dilute and give slowly
IV
per injection site
PO

2004). Intravenous administration of oxytetracycline @ $11 \mathrm{mg} / \mathrm{kg}$ twice in a day, maintain mean tissue concentration $>5 \mu \mathrm{g} / \mathrm{g}$ in the uterine wall for the first 4 hours after the first treatment and reaching a maximum of 9 hours by the 5th day of treatment. Slightly higher and more persistent concentrations of 
oxytetracycline were found in the caruncles and endometrium for a long periods of time. Concentrations in the uterine wall were far below those of blood (Bretzlaff, 1983). The minimum inhibitory dose for Arcanobacter pyogenes in uterine isolates is reported to be $20.4 \mu \mathrm{g} / \mathrm{mL}$. A single IM administration of oxytetracycline has been reported to improve fertility as well as to treat subclinical endometritis (Tek et al., 2010).

\section{Hormone therapy}

Hormone therapy is another good alternative optional treatment protocol. The therapeutic action of hormone is to increase expulsive uterine contractions or to induce an estrus (Laven, 2003; Heuwieser et al., 2000).

Therapeutic action of estrus are well known during this increase neutrophil function under the influence the estrogen, makes uterus resistance to infection (Smith and Risco, 2002) and increase myometrial contractility are all reduced under the influence of progesterone (Frazer 2001).

Induction of estrus is the effective treatment for metritis (Heuwieser et al., 2000; Laven, 2003). During estrus there is naturally effective expulsion of uterine contents and in this state stimulate the uterine defense mechanisms to a very high level. The benefits of estrus are well-recognized since neutrophil function, uterine resistance to infection (Roberts, 1986; Bretzlaff, 1987). The corpus luteum destroyed by the action of estrogen or prostaglandin, leading to estrus induction. Prostaglandin F2 $\alpha$ and various analogs have been widely used for the treatment of postpartum metritis. The uses of prostaglandin F2 $\alpha$ and its analog in the immediate postpartum period, attempt to increase uterine tone to induce estrus (Bretzlaff, 1987; Hussain, 1989). However, it is proven that PGF has effect if there is luteal tissue present on the ovary and progesterone level is high (Le Blanc et al., 2002). Use of cyclooxygenase inhibitors (NASADS) reduces the PGF production, but it don't effects on the rate of involution in size of the uterus and cervix is unaffected by $80 \%$ decline in PGF production (Steffan et al., 1984; Frazer, 2001). Intramuscular injection of PGF at high dose $50 \mathrm{mg}$ has not had any apparent effect on uterine tone. Other hand Intravenous injection in lower doses have been much more effective, but only up to 4days postpartum (Laven, 2003; Frazer, 2001). This may due to IM injections are absorbed more slowly and, once absorption occurs, PGF is metabolized on a single pass through the lungs. The benefits of prostaglandin in the postpartum cow may relate to its role in the inflammatory process, but this hypothesis has yet to be validated (Frazer, 2001; Sheldon and Noakes, 1998). Estrogens, more commonly estradiol cypionate, have been used to formation of oxytocin receptors in the postpartum uterus. It has been proven that estradiol will speed up the process of oxytocin receptor expression in cyclic cattle, but it is not always essential for the process for all times postpartum (Hixon and Flint, 1887).

Estradiol at doses of 5-10 mg per animal has been used as treatment for postpartum endometritis and is almost effective as PGF2 (Pepper and Dobson, 1987; Sheldon and Noakes, 1998). But as the adverse effect of it to lactating cows can suppress milk production and can also result into formation of ovarian cysts (Roberts, 1986; Jeengar et $a l ., 2014$ ) and so that the use of estrogens is not advocated on a wider scale and should be limited to a short term therapy only under specific circumstances. Estrogen may be used alone for metritis treatment. Recommended doses of estradiol range from 3-10 $\mathrm{mg}$ and doses may be repeated twice at 3 day intervals. Furthermore, the use of $5 \mathrm{mg}$ of ECP IM 18-hours post-partum was found to 
negatively affect the frequency and duration of uterine contractility for at least 5 days (Wiltbank et al., 2000).

Oxytocin is inexpensive drug, but is thought to be useless to uterine clearance after long period in postpartum cow. It is well known that there is a loss of oxytocin receptors in the myometrium effective till 48-hours postpartum. Problem with oxytocin is its short duration of therapeutic action so repeated doses required for desirable action (Gustafsson, 1984). Repeated daily dosing of oxytocin following the single estrogen injection did not produce a demonstrable benefit. It have been demonstrated that uses of estrogen causes, uterine contractions are toward cervico-tubal. It may be a reason for the high incidence of salpingitis in a study where cows with metritis were treated with 10 mg of estrogen IM. With ECP treatment there is increased incidence of cystic ovarian degeneration (Smith and Risco 2002). Oxytocin used in post-dystocia or post caesarean to treat uterine atony, placental expulsion, and to prevent uterine prolapse. To till date, it is has been not clear to determine the most appropriate dose, A study evaluate oxytocin dose as a treatment for Retention of fetal membrane, 60 IU oxytocin IV was found to result more effective (Frazer, 2001).

Continuous slow IV infusion of oxytocin in saline over 6 hours would may be more appropriate, but this difficult to maintain such a period in large animal (Gilbert and Schwark 1992). The increased frequency of uterine contractions has been to be similar to as in early stage II of parturition in cattle. Most of the studies used IV route of administration for oxytocin. Same responses have been also found following IM or SC uses with different doses. However critical, scientific evaluation has yet to be done to determine its effectiveness (Frazer, 2001). Ergonovine is a fungal derivative and not actually a hormone.
It is known for uterine contraction stimulation, otherhand controlled trials have shown little or no effect on myometrial contraction (Gustafsson 1984).

\section{Alternative treatment}

Vitamin E and selenium increase chemotaxis and leukocyte numbers at the fetomaternal junction, thus contributing to the normal expulsion of fetal membranes, ultimately reduces the chances of infections (Bourne et al., 2007).

Calcium is an essential trace-element that results smooth muscle contraction of the uterus. Immediately after calving most of the high yielding cows becomes deficienct in calcium leading to atonicity of the uterine musculature which ultimately causes retention of fetal membranes and metritis (Al-Eknah 1989; Whiteford, 2005). Therefore, prescribing oral calcium during this period may be beneficial to prevent metritis. Sometimes after calving, cows loss their appetite and there are many chances of developing ketosis in such animals which causes displaced abomasums or metritis. In such conditions supplementation with propylene glycol or propionate is beneficial (Littledike, 1981).

In conclusion, uterine infection after calving is the most important cause of infertility in dairy animals. Predisposing factors for establishment of uterine infections are RFM dystocia, caesarean section, still birth. Severity of uterine infection depends totally on the immune response of the animal and the types and load of bacteria. Bactria multiply and penetrate the mucosal epithelium, release bacterial toxins that causes to establishment of uterine infection. Postpartum uterine infections disturbs the normal cyclicity of animal, intrauterine transport of sperm and embryo implantation these factor leads to 
delayed calving to first service interval and reduced conception rates finally economic losses to the owner. Treatment with intrauterine therapy alone in case of endometritis may gives a good result but in the case of metritis parental antibiotic infusion only gives results. Ceftiofur is good treatment of choice for metritis. Provides proper nutrition during pregnancy, hygienic conditions during calving and immediate veterinary care in case of dystocia to reduce the postpartum uterine infections.

\section{References}

Aghamiri, S.M., Haghkhah, M., Ahmadi, M.R. and Gheisari, H.R. 2014. Development of a multiplex PCR for the identification of major pathogenic bacteria of post-partum endometritis in dairy cows. Reproduction In Domestic Animals, 49, 233-238.

Al-Eknah Mm, Noakes De. A Preliminary Study On The Effect Of Induced Hypocalcaemia And Nifedipine On Uterine Activity In The Parturient Cow. J. Vet. Pharmacol. Ther., 1989; 12: 237-239.

Amiridis, G.S., Fthenakism G.C., Dafopoulos, J., Papanikolaou, T And Vrogianni, T.S. 2003. Use of cefquinome for prevention and treatment of bovine endometritis. Journal Of Veterinary Pharmacology And Therapeutics, 26: 387-390.

Anilkumar, R. and Devanathan, T.G. (1996). Correlation between white side test for quality of cervical mucus and sperm penetration test. Indian Vet. J., 73: 10991100

Au, Y.P., Montgomery, K.F. and Clowes, A.W. 1992. Heparin inhibits collagenase gene expression mediated by Phorbol esterresponsive element in primate arterial smooth muscle cells. Circulation Research, 70, 1062-1069.

Azawi, O.I. 2008. Postpartum uterine infection in cattle. Animal Reproduction Science, 105: 187-208.

Bar D., Ezra E. (2005): Effects of common calving diseases on milk production in high yielding dairy cows. Israel Journal Of Veterinary Medicine, 60, 106-111.

Barlund, T.D., Carruthers, T.D., Waldner, C.L and Palmer, C.W. 2008. A comparison of diagnostic techniques for postpartum endometritis in dairy cows. Theriogenology, 69: 714-723.

Bartolome, J.A., Khalloub, P., De La Sota. L., Drillich, M and Melendez, P.G. 2014. Strategies for the treatment of dairy cows at high risk for postpartum endometritis and for the treatment of clinical endometritis in Argentina. Tropical Animal Health And Production, 46: 79-85.

Beagley J.C., Whitman K.J., Baptiste K.E., And Scherzer J. (2010) Physiology and treatment of retained fetal membranes in cattle. J Vet Intern Med 24: 261-268.

Beverly, J. R. 1985. Reproduction in beef cattle as related to nutrition and body condition. Kentucky roundup of reproductive efficiency in beef cattle. Pp.1-12.

Bondurant, H. 1999. Inflammation in the bovine reproductive tract. Journal of Dairy Science, 82(Suppl2): 101-110.

Bonnett, B.N., Martin, S.W and Meek A.H. 1993. Associations of clinical fidings, bacteriological and histological results of endometrial biopsy with reproductive performance of postpartum dairy cows. Preventive Veterinary Medicine, 15: 205220.

Bonnett, B.N., Martin, S.W., Gannon, V.P., Miller, R.B and Etherington, W.G. 1991. Endometrial biopsy in Holstein-Friesian dairy cows. Iii. Bacteriological analysis and correlations with histological findings.

Canadian Journal of Veterinary Medicine, 55: 168-173.

Bourne, N., Laven, R., Wathes, D.C., Martinez, T And Mcgowan, M. 2007. A metaanalysis of the effects of vitamin e supplementation on the incidence of retained foetal membranes in dairy cows. Theriogenology, 67: 494-501.

Bretzlaff Kn, Ott Rs, Koritz Gd, Bevill Rf, Gustafsson Bk, Davis Le. 1983. Distribution of oxytetracycline in genital tract tissues of postpartum cows given the 
drug by intravenous and intrauterine routes. Am J Vet Res; 44:764-769.

Bretzlaff, K., 1987. Rationale for treatment of endometritis in dairy cows. Vet. Clin. North Am. Food Anim. Prac. 3, 593-598.

Bretzlaff, K.N., 1986. Factors of importance for the disposition of antibiotics in the female genital tract. In: Morrow, D.A.(Ed.), Current Therapy Of Theriogenology. W.B. Saunders Co., Philadelphia, Pa, Pp. 34-47.

Bruun, J., Ersbull, A.R. and Alban, L. 2002. Risk factors for metritis in danish dairy cows. Preventive Veterinary Medicine 54, 179-190.

Buckley, F., Dillon, P. and Mee, J.F. 2010. Major Management Factors Associated With The Variation In The Reproductive Performance In Irish Dairy Herds. Final Report Project, 5070.

Buttler, W.R. and Smith, R.D., 1989. Interrelationship between energy balance and postpartum reproductive function in dairy cattle. J. Dair. Sci. 72: 767-783.

Cady, R.A., 2010. Dystocia-difficult calving, what it costs and how to avoid it. Dairy International Reproduction Management, 20, 1-5.

Callahan, C.J And Horstman, L.A. 1987. Treatment of early postpartum metritis in a dairy herd: response and subsequent fertility. Bovine Practitioner, 22: 124-128.

Campo, E., Alonso, J.C., Hincapie, J.J., Garcia, L., Faure, O. and Fernandez, O. 2002. Seasonal influence on uterine involution and postpartum ovarian activity in river buffaloes. Bubalus Bubalis, 8(3), 59-63.

Carrière Pd, Descôteaux L, Durocher J.(2002). Evaluation Échographique Du Tractus Reproducteur Bovin: Développement Normal Et Anormal Des Follicules Ovariens Et Du Corps Jaune. Méd Vét Du Québec, 32:128-131.

Correa, M. T., H. Erb, and J. Scarlett. 1993. Path analysis for seven postpartum disorders of holstein cows. J. Dairy Sci. 76:1305- 1312.

De Bois, C.H.W and Manspeaker, J.E. 1986. Endometrial biopsy in the bovine. In: Morrow Da (Ed) Current Therapy In
Theriogenology. W B Saunders Co. Philadelphia Pp 424427.

Devine, D. A. and Lindsay, F. E. (1984) Hysteroscopy in the cow using a flexible fibrescope. Veterinary Record 115, 627628.

Dohmen, M.J., Lohuis, J.A.C.M., Huszeniczea, G., Nagy, P and Gacs, M. 1995. The relationship between bacteriological and clinical fidings in cows with sub acute/ chronic endometritis. Theriogenology, 43: 1379-1388.

Dolatkhah, B., Mahdavi, A.H., Rahmani, H.R., Edriss, M.A and Khorvash, M. 2013. Cytologic and histologic characteristics of endometritis in postpartum dairy cows. Annals Of Biological Research, 4:70-76.

Drillich, M., Pfutzer, A. and Sabin, H.J. 2003. Comparison of two protocols for treatment of retained fetal membranes in dairy cattle. Theriogenology, 59: 951-960.

Eiler, H., and Fecteau, K.A. 2007. Retained Placenta. In: Youngquist, R.S. and Threlfall, W.R. Editors. Current therapy in large animal theriogenology, 2nd Edition St Louis, Mo: Wb Saunders. Pp 345-354.

Erb, R.E., Hinze, P.M., Gilda, E.M. and Morrison, R.A., 1985. Retained fetal membranes: the effect on prolificacy of dairy cattle. J. Am.Vet. Med. Assoc. 133: 496. Morrow, D.A, 1969. Postpartum ovarian activity and involution of the uterus and cervix in dairy cattle. Vet. Scope. 14: 2-13.

Esslemont, R. J. And Kossaibati, M. A. (2002) Daisy Research Report No. 5: The costs of poor fertility and disease in UK dairy herds - trends in daisy herds over 10 seasons, Intervet Uk Ltd, Milton Keynes.

Foldi, J., Kulksar, M., Pecsi, A. and Lohuis, J.A.C.M. 2006. Bacterial complications of postpartum uterine involution in cattle. Animal Reproduction Science, 96, 265281.

Fourichon, C., H. Seegers, and X. Malher. 2000. Effect of disease on reproduction in the dairy cow: a meta-analysis. Theriogenology 53:1729-1759. 
Fourichon, C., H. Seegers, N. Bareille, and F. Beaudeau. 1999. Effects of disease on milk production in the dairy cow: a review. Prev. Vet. Med. 41:1-35.

Gautam, G., Nakao, T., Koike, K., Long, S.T., Yousuf, M., Ranasinghe R.M.S.B.K. and Hayashi, A., 2010. Spontaneous recovery or persistence of postpartum endometritis and risk factors for its persistence in holstein cows. Theriogenol. 73:168-179

Gilbert, R.O and Schwark, D.S. 1992. Management of peripartum condition in the cow. Veterinary Clinics Of North America Food Animal Practice, 8: 40-55.

Gilbert, R.O., Shin, S.T., Guard, C.L., Erb, H.N and Frajblat, M. 2005. Prevalence of endometritis and its effects on reproductive performance of dairy cows. Theriogenology, 64: 1879-1888.

Gröhn, Y. T., H. N. Erb, C. E. Mcculloch, And H. S. Saloniemi. 1990. Epidemiology of reproductive disorders in dairy cattle: associations among host characteristics, disease and production. Prev. Vet. Med. 8:25-39.

Gupta, S., Gupta, H. and Soni, J. 2005. Effect of vitamin e and selenium supplementation on concentration of plasma cortisol and erythrocyte lipid peroxidases and the incidence of retained fetal membranes in crossbred dairy cattle. Theriogenology, 64, 1273- 1286.

Gustafsson, B.K. 1984. Therapeutic strategies involving antimicrobial treatment of the uterus in large animals. Journal of American Veterinary Medical Association, 185: 1194-1198.

Hendricks, K.E.M., Bartolome, J.A., Melendez, P., Risco, C. and Archbald, L.F., 2006. Effect of repeated administration of $\mathrm{Pgf} 2 \mathrm{a}$ in the early postpartum period on the prevalence of clinical endometritis and probability of pregnancy at first insemination in lactating dairy cows. Theriogenol. 65: 1454-1464.

Herath, S., Lilly. S.T., Fischer, D.P., Williams, E.J., Dobson, H., Bryant, C.E. and Sheldon, I.M., 2009. Bacterial Lipopolysaccharide Induces An Endocrine
Switch From Prostaglandin F2 $\alpha$ To Prostaglandin E2 In Bovine Endometrium. Endocrinology. 150:1912-20.

Heuwieser, W., Tenhagen, B.A., Tischer, M., Luhr, J And Blum, H. 2000. Effect Of Three Programmes For The Treatment Of Endometritis On The Reproductive Performance Of A Dairy Herd. Veterinary Record, 146: 338-341.

Hixon Je, Flint Ap. effects of a luteolytic dose of oestradiol benzoate on uterine oxytocin receptor concentrations, phosphoinositide turnover and prostaglandin F-2 Alpha Secretion In Sheep. J Reprod Fertil. 1987;79:457-467.

Hossein-Zadeh, N.G., 2010. The effect of twinning on milk yield, dystocia, calf birth weight and open days in holstein dairy cows of Iran. Journal Of Animal Physiology And Animal Nutrition, 94, 780787.

Hussain, A.M. 1989. Bovine uterine defense mechanisms: a review. Journal of Veterinary Medicine, 36: 641-651.

Jeengar, K., Chaudhery, V., Kumar, A., Raiya, S., Gaur, M And Purohit, G.N. 2014. Ovarian cysts in dairy cows: old and new concepts for definition, diagnosis and therapy. Animal Reproduction, 11: 63-73.

Juchle, W., 1981. Bovine Practitioner 16:65 Cited by O. Maarkusfeld (1984). Factors Responsible For Postpartum Metritis In Dairy Cattle. Vet. Rec. 114: 539-542.

Kasaimanickam, R., Duedd, T.F., Foster, R.A., Gartley, C.J., Lesly, K.E., Watson, J.S and Johnson, J.H. 2004. Endometrial cytology and ultrasonography for the detection of subclinical endometritis in postpartum dairy cows. Theriogenology, 62: 9-23.

Kasaimanickam, R., Duffield, T.F., Foster, R.A., Gartley, C.G., Leslie, K.E., Walton, J.S and Johnson, W.H. 2005. The effect of a single administration of cephapirin or cloprostenol on the reproductive performance of dairy cows with subclinical

endometritis. Theriogenology, 63: 818830 . 
Kaufmann, T.B., Westermann, S., Holtz, J And Heuwieser, W. 2010. Systemic antibiotic treatment for endometritis in dairy cows with ceftiofur or two doses of cloprostenol in A 14-D Interval. Animal Reproduction Science, 121: 55-62.

Kendric, J.W., 1980. Proceedings of the $11^{\text {th }}$ international congress on diseases of cattle medrid. P. 773.

Kim, I.H., and Kang, H.C. 2003. Risk factors for postpartum endometritis and the effect of endometritis on reproductive performance in dairy cows in Korea. Journal of Reproduction And Development, 49, 485-491.

Konigsson, K., Gustafsson, H., Gunnarsson, A., Kindahl, H., 2001. Clinical and bacteriological aspects on the use of oxytetracycline and flunixin in primiparous cows with induced retained placenta and postpartal endometritis. Reprod. Dom. Anim. 36, 247.

Konyves, L., Szenci, O., Jurkovich, V., Tegzes, L., Tirian, A., Solymosi, N., Gyulay, G. and Brydl, E. 2009. Risk assessment of postpartum uterine disease and consequences of puerperal metritis for subsequent metabolic status, reproduction and milk yield in dairy cows. Acta Veterinaria Hungarika, 57, 155-169.

Kossaibati, M.A. And Esslemont, R.J. 1997. The costs of production diseases in dairy herds in England. Veterinary Journal, 154, 41-51.

Kumar, P., Purohit, G.N and Mehta, J.S. 2013. Diagnosis and therapy of endometritis using metricheck, uterine cytology and ultrasonography and the efficacy of different treatments. Veterinary Practitioner, 14: 351-354.

Laven, R.A. 2003. Understanding the dynamics of bovine endometritis: comparison of the response to injectable luprostiol and topical cephapirin. Cattle Practice, 11: 263-270.

Leblanc SJ. postpartum uterine disease and dairy herd reproductive performance: a review. Vet J. 2008; 176: 102-14.
Leblanc, S.J., Duffield, T.F., Leslie, K.E., Keefe, G.P., Walton, J.S. and Johnson, W.H. 2002. Defining and diagnosing clinical endometritis and its impact on reproductive performance in dairy cows. Journal Of Dairy Science, 85, 2223-2236.

Lenz M, Drillich M. and Heuwieser W. (2007). Evaluation of the diagnosis of subclinical endometritis in dairy cattle using ultrasound. Berl Munch Tiera. Woch.. 120: 237-44.

Leutert, C., Kruger, S,V., Plontzke, J and Heuweiser, W. 2012. Evaluation of vaginoscopy for the diagnosis of clinical endometritis in dairy cows. Journal of Dairy Science, 95: 206-212.

Li Yan, Z And Lian, L.J. 2008. Study on therapeutic effect of florfenicol suspension on endometritis in dairy cows. China Dairy Cattle, 2: 29-31.

Littledike Et, Young Jw, Beitz Dc. Common metabolic diseases of cattle: ketosis, milk fever, grass tetany, and downer cow complex. J Dairy Sci. 1981; 64(6): 1465-1482.

Lucy Mc. 2017. Hot topic: 16s rRNA gene sequencing reveals the microbiome of the virgin and pregnant bovine uterus. J Dairy Sci, 100:4953-4960.

Madoz, L.V., Sota, R.L. De. La., Suzuki, K., Heuwieser, W and Drillich, M. 2010. Use of hysteroscopy for the diagnosis of postpartum clinical endometritis in dairy cows. Veterinary Record, 167: 142-143.

Mahto, D., Sinha, M.P., Singh, B and Jha, D.K. 2012. Effect of systemic and intrauterine administration of drug on endometritis in cow. Indian Journal of Animal Reproduction, 33: 51-53.

Malinowsk, E., Kuzma, K., Zietara, J., Nandotry, M., Niewitecke, M.S., Niliski, S and Kacmarowski M. 2004. The use of gynobiotic in therapy and prophylaxis of endometritis in cows. In: Proceedings 5th Middle-European Buiatrics, Co, Poland. 165-169.

Markusfeld, O., 1984. Factors responsible for post parturient metritis in dairy cattle. Vet. Rec. 114: 539-542. 
Markusfeld, O., 1987. Periparturient traits in seven high dairy herds. Incidence rates, association with parity, and interrelationships among traits. J. Dair. Sci. 70: 158-66.

Mcdougall, S., 2001. Effects of periparturient diseases and conditions on the reproductive performance of New Zealand Dairy Cows. New Zealand Veterinary Journal, 49:60-68.

Mcdougall, S., Mccaulay, R and Compton, C, 2007. Association between endometritis diagnosis using a novel intravaginal device and reproductive performance in dairy cattle. Animal Reproduction Science, 99: 9-23.

Meira Junior, E.B.S., Henriques, L.C.S., Sa, L.R.M and Gregory, L. 2012. Comparison of ultrasonography and histopathology for the diagnosis of endometritis in Holstein Friesian cows. Journal Of Dairy Science, 95: 6969-6973.

Menadoric, M., Radakovic, N. and Karadzic, V., 1979. Relationship between the occurrence of acetonemia and endometritis and various production and breeding indices in Holstein-Friesian First Calvers. Veterinarski Glasnik. 33:558562.

Metzner, M., Lessmann, H. W. and Merck, C. C. (1992) Hysteroscopy as a diagnostic aid for uterine diseases of cattle. Tierärztliche Praxis 20, 364-367.

Miller, H.V., Kimsey, P.B., Kendrick, J.W., Darien, B., Doering, L., Franti, C and Horton, J. 1980. Endometritis of dairy cattle: diagnosis, treatment, and fertility. Bovine Practitioner, 15: 13-23.

Miller, H.V., Kimsey, P.B., Kendrick, J.W., Darien, B., Doering, L., Franti, C and Horton, J. 1980. Endometritis of dairy cattle: diagnosis, treatment, and fertility. Bovine

Practitioner, 15: 13-23.

Milosh, P., Ivan, P., Slobodanka, V., Dobrila, J.D., Voislav, P., Mile, D., Marina, R., Svetlana, N and Milan, M. 2013. Comparison of microbiological and endoscopy diagnostic of uterine disease in infertility of dairy cattle. Proceedings 4th
International Scientific Meeting, 6-8 September, Republic Of Macedonia, Pp 51-52.

Muller, L.D. And Owens, H.J., 1974. Factors associated with the incidence of retained placenta. J. Dairy. Sci. 57: 725.

Nakova, T., Moriyoshi, M. and Kawata, K., 1992. The effect ovarian dysfunction and endometritis on subsequent reproductive performance in dairy in dairy cows in Korea. Theriogenology. 37; 341-9.

Noakes, D.E., Wallace, L and Smith, G.R. 1991. Bacterial flora of the uterus of cows after

calving on two hygienically contrasting farms. Veterinary Record, 128: 440-442.

Olson Jd, Ball L, Mortimer Rg. Therapy of postpartum uterine infections. Proc Ann Convam Assoc Bovine Prac. 17: 85. 1985.

Olson, J.D., Ball, L., Mortimer, R.G., Faren, P.W., Adney, W.S. and Huffman, E.M., 1984. Bacteriology of pyometra in dairy cow. Proc. Xth. Int. Cong. Anim. Reprod. And Ai. Urbana 4. 25-51.

Olson, J.D., Bretzlaff, K.N., Mortimer, R.G And Ball, L. 1986. The metritis-pyometra complex. In: Current Therapy In Theriogenology-2, Morrow D.A (Ed), Wb Saunders Co Philadelphia. Pp. 227-236.

Onyango, J., 2014. Cow postpartum uterine infection: a review of risk factors, prevention and the overall impact. Veterinary Research International, 2, 1832.

Opsomer, G., And Kruif, A. 2009. Metritis and Endometritis in high yielding dairy cows. Vlaams Diergeneeskundig Tijdschrift, 78, 83-88.

Oral, H., Sozmen, M., Serin, G And Kaya, S. 2009. Comparison Of The Cytobrush technique, vaginoscopy and transrectal ultrasonography methods for the diagnosis of postpartum endometritis in cows. Journal of Animal And Veterinary Advances 8: 1252-1255.

Ott Jm. Treatment of toxic metritis in dairy cattle. Comp Contin Educ Pract Vet., 1986; 8: S321-S327. 
Paisley, L.G., Mickelsen, W.D., Anderson, P.B., 1986. Mechanisms and therapy for retained fetal membranes and uterine infections of cows: A Review. Theriogenology 25, 353-381.

Pepper, R.T and Dobson, H. 1987. Preliminary results of treatment and endocrinology of chronic endometritis in the dairy cow. Veterinary Record, 120: 53-56.

Peters Ar, Laven Ra. Treatment of bovine retained placenta and its effects. Vet Rec 1996; 139(22): 535-539.

Potter, T.J., Guitian, J., Fishwick, J., Gordon, P.J. and Sheldon, I.M. 2010. Risk factors for clinical endometritis in postpartum dairy cattle. Theriogenology, 74, 127- 134.

Pugh Dg, Lowder Mq, Wenzel, Jgw. Retrospective analysis of the management of 78 cases of postpartum metritis in the cow. Theriogenology 1994;42:455-463.

Purohit, G.N and Sharma, A. 2007. Effect of ciprofloxacin therapy in endometritis of cows. Indian Journal of Animal Reproduction, 28: 37-38.

Purohit, G.N. 2008. Recent developments in the diagnosis and therapy of repeat breeding cows and buffaloes. Cab Reviews: Perspectives In Agriculture, Veterinary Science, Nutrition And Natural Resources, 3(062): 1-34.

Raja, S., Devanathan, T.G., Kulasekar, K., Pazhanivel, N and Balachandran, C. 2012. Whiteside test and endometrial biopsy for diagnosis of endometritis in repeat breeding cows. Indian Journal Of Animal Reproduction, 33: 56-58.

Rekwot, P.I., Ogwu, D. and Oyedipe, E.O. 2000. Influence of bull biostimulation, season and parity on resumption of ovarian activity of zebu (Bos Indicus) Cattle Following Parturition. Animal Reproduction Science, 63(1-2), 1-11.

Roberts, S.J., 1986. Veterinary Obstetrics And Genital Diseases, Third Ed. S.J. RobertsWoodstock, Ny, Pp. 381-359.

Ruder, C.A., Sasser, R.G., Williams, R., Kelly, J.K., Bill, R.C. and Butler, J.F., 1981. Uterine infections in the postpartum cow. Ii. possible synergistic effect of
Fusobacterium necrophorum and Corynebacterium Pyogenes. Theriogenol. 15: 573-580.

Runciman, D.J., Anderson, G.A and Malmo, J. 2009. Comparison of two methods of detecting purulent vaginal discharge in postpartum dairy cows and effect of intrauterine cephapirin on reproductive performance. Australian Veterinary Journal, 87: 369-78.

Runciman, D.J., Anderson, G.A., Malmo, J and Davis, G.M. 2008a. Use of postpartum vaginoscopic (visual vaginal) examination of dairy cows for the diagnosis of endometritis and the association of endometritis with reduced reproductive performance. Australian Veterinary Journal, 86: 205-13.

Sandals, W.C.D., Curtis, R.A., Cote, J.F. and Marion, S.W, 1979. The effect of retained placenta and metritis complex of reproductive performance in dairy cattle: a case control study. Can. Vet. J. 20: 131139.

Seguin, B.E., Morrow, D.A., Oxender, W.D., 1974. Intrauterine therapy in the cow. Javma 164, 609-612.

Selk, G. E., R. P. Wettemann, K. S. Lusby, and R. J. Rasby. 1986. The importance of body condition at calving on reproduction in beef cows. Osu Agric. Exp. Sta. Publ. 118:3163-3169.

Sheldon, I. M., and H. Dobson. 2004. Postpartum Uterine Health In Cattle. Anim. Reprod. Sci. 82-83:295-306.

Sheldon, I.M., Lewis, G.S., Le Blanc, S And Gilbert, R.O. 2006. Defining Postpartum Uterine Disease In Cattle. Theriogenology, 65: 1516-1530.

Sheldon, I.M., Noakes, D.E., Rycroft, A.N and Dobson, H. 2002. Effect of postpartum manual examination of the vagina on uterine bacterial contamination in cows. Veterinary Record, 151: 531-534.

Sheldon, I.M., Noakes, D.E., Rycroft, A.N., Pfeiffer, D.U., Dobson, H., 2002b. Influence of uterine bacterial contamination after parturition on ovarian dominant follicle selection and follicle 
growth and function in cattle. Reproduction 123, 837-845.

Sheldon, I.M., Rycroft, A.N and Zhou, C. 2004. Association Between Postpartum Pyrexia And Uterine Bacterial Infection In Dairy Cattle. Veterinary Record, 154: 289-293.

Singh, A.K., Aghtor, P.G., Singh, R.B., Singh, A.P and Verma, S.B. 2001. efficiency of treatment of endometritis with chemotherapeutic agents in cows and buffaloes. Indian Journal of Animal Reproduction, 2: 9-12.Paisley Lg, Micklesen

Smith, B.I., and Risco, C.A. 2002. Predisposing Factors And Potential Causes Of Postpartum Metritis In Dairy Cattle. Food Animal Compendium, 24, 56-63.

Somasekara, N., 2003. Therapeutic efficacy of prostaglandin $\mathrm{f} 2 \alpha$ in the treatment of bovine postpartum metritis. $M$ ' $V$ ' Sc, Thesis Submitted To University Of Agricultural Sciences, Bangalore.

Sood, P., Verma, S., Mahajan, A., Singh, M., Vasistha, N.K and Katoch, R.C. 2002. Microbiological profile in cyclic endometritic cows of Palam Valley of Himachal Pradesh. Indian Journal Of Animal Sciences, 72: 251-252.

Steffan, J., Agric, M., Adriamanga, S and Thibier, M. 1984. Treatment of metritis with antibiotics or prostaglandin $\mathrm{f} 2 \alpha$ and influence of ovarian cyclicity in dairy cows. American Journal of Veterinary Research, 45: 1090-1094.

Studer, E and Morrow, D.A. 1978. Postpartum evaluation of bovine reproductive potential: comparison of fidings from genital tract examination per rectum, Uterine Culture, And Endometrial Biopsy. Journal Of American Veterinary Medical Association, 172: 489-494.

Sunilchandra, U and Hiremath, S. 2004. Efficacy of ciprofloxacin in uterine infection of the bovines. Intas Polivet, 5: 207-208.

Tek, C., Sabuncu, A., İKiZ, S., BağCigiL, F., Gündüz, M.C., KiliçArslan, M.R and Özgür, Y. 2010. The effect of a single administration of parenteral oxytetracycline and flunixinmeglumine combination on the reproductive performance of dairy cows with subclinical endometritis. Turkish Journal Of Veterinary And Animal Science, 34: 319325.

Tsousis, G., Sharifi, R. and Hoedemaker, M. 2009. Association between clinical signs of chronic endometritis with ovarian cysts and body condition loss in german holstein friesian cows. Journal of Veterinary Science, 10, 337341.

Van Werven, T., Y.H. Schukken, J. Lloyd, A.Br. and H.Tj. Heeringa. (1992) The effects of duration of retained placenta on reproduction, milk production, postpartum disease and culling rate. Volume 37 , Issue 6, Pages 1191-1203.

Veterinary Pharmaceuticals and Biologicals, 6th Edition. Lenexa Kansas: Veterinary Medicine Publishing Co. 1988.

Westermann, S., Drillich, M., Kaufmann, T.B., Madoz, L.V And Heuweiser, W. 2010. A clinical approach to determine false positive findings of clinical endometritis by vaginoscopy by the use of uterine bacteriology and cytology in dairy cows. Theriogenology, 72: 1248-1255.

Williams, E.J., Fischer, D.P., Pfeiffer, D.U., England, G.C.W., Noakes, D.E., Dobson, $\mathrm{H}$ and Sheldon, I.M. 2005. Clinical evaluation of postpartum vaginal mucus reflects uterine bacterial infection and the immune response in cattle. Theriogenology, 63: 102-117.

Wiltbank Mc, Fricke Pm, Sangsritavong S, Sartori R, Ginter Oj. Mechanisms That Prevent And Produce Double Ovulation In Dairy Cattle. J Dairy Sci 2000; 83: 29983007.

Youngquist Rs, Shore Md. Postpartum Uterine Infections. In: Youngquist Rs, Ed. Current Therapy In Large Animal Theriogenology. Toronto: Wb Saunders Company; 1997: 335-340.

Zaborski, D., Grzesiak, W., Szatkowska, I. Dybus, A., Muszynska, M. and Jedrzejczak, M. 2009. Factors affecting 
dystocia in cattle. Reproduction In Domestic Animals, 44, 540-551.

Zezula-Spyra A., Glazer, T., Zdunczyk, S., Ras, A., Kulharski, J., Janiwas, K.I.T. and Chmicl, J., 1990. Studies on some factors influencing the prevalence of endometritis in cows in the postpartum period. Acta. Acad. Agri.Tech. Olstenensis 18: 95-102.

\section{How to cite this article:}

Devender Kumar, Satish and Purohit, G.N. 2019. A Discussion on Risk Factors, Therapeutic Approach of Endometritis and Metritis in Cattle. Int.J.Curr.Microbiol.App.Sci. 8(05): 403-421. doi: https://doi.org/10.20546/ijcmas.2019.805.048 